\title{
Infiltrative Growth Pattern
}

National Cancer Institute

\section{Source}

National Cancer Institute. Infiltrative Growth Pattern. NCI Thesaurus. Code C41453.

A microscopic finding indicating that the neoplastic cells exhibit an infiltrating growth in a tumor sample. 